\title{
Determinants of soluble angiotensin-converting enzyme 2 concentrations in adult patients with complex congenital heart disease
}

\author{
Tanja Raedle-Hurst ${ }^{1}$ (D) $\cdot$ Sarah Wissing ${ }^{1} \cdot$ Nils Mackenstein $^{1} \cdot$ Rima Obeid $^{2} \cdot$ Juergen Geisel $^{2} \cdot$ Stefan Wagenpfeil $^{3}$. \\ Hashim Abdul-Khaliq ${ }^{1}$
}

Received: 21 September 2020 / Accepted: 16 November 2020 / Published online: 5 December 2020

(c) The Author(s) 2020

\begin{abstract}
Background Angiotensin-converting enzyme (ACE) 2 is known to be a functional receptor for SARS-CoV-2 in the current pandemic. Soluble ACE2 (sACE2) concentrations are elevated in patients with various cardiovascular disorders including heart failure.

Methods In a total of 182 consecutive adult patients with complex congenital heart disease (CHD) and 63 healthy controls, sACE2 concentrations were measured in serum using the Human ACE $2^{\circledR}$ assay by Cloud-Clone Corporation and associated with clinical, laboratory and echocardiographic parameters.

Results Median sACE2 levels were increased in patients with complex CHD as compared to healthy controls (761.9 pg/ml vs $365.2 \mathrm{pg} / \mathrm{ml}, p<0.001)$. Moreover, sACE2 concentrations were significantly elevated in patients with a higher NYHA class $\geq$ III $(1856.2 \mathrm{pg} / \mathrm{ml}$ vs $714.5 \mathrm{pg} / \mathrm{ml}$ in patients with NYHA class I/II, $p<0.001)$. Using linear regression analysis, higher sACE2 levels were associated with a higher NYHA class $\geq$ III, more severe CHD, a morphological left systemic ventricle, higher creatinine and the use of mineralocorticoid receptor antagonists (MRA) in the univariable model. The use of ACE inhibitors or angiotensin receptor blockers (ARB) was associated with lower sACE2 levels. In the multivariable model, higher sACE2 levels were independently associated with a higher NYHA class $\geq$ III $(p=0.002)$ and lower sACE2 levels with the use of ACE inhibitors or ARB $(p=0.001)$.

Conclusion Soluble ACE2 concentrations were significantly increased in all types of complex CHD with highest levels found in patients with NYHA class $\geq$ III. Moreover, a higher NYHA class $\geq$ III was the most significant determinant that was independently associated with elevated sACE2 concentrations.
\end{abstract}

\section{Graphic abstract}
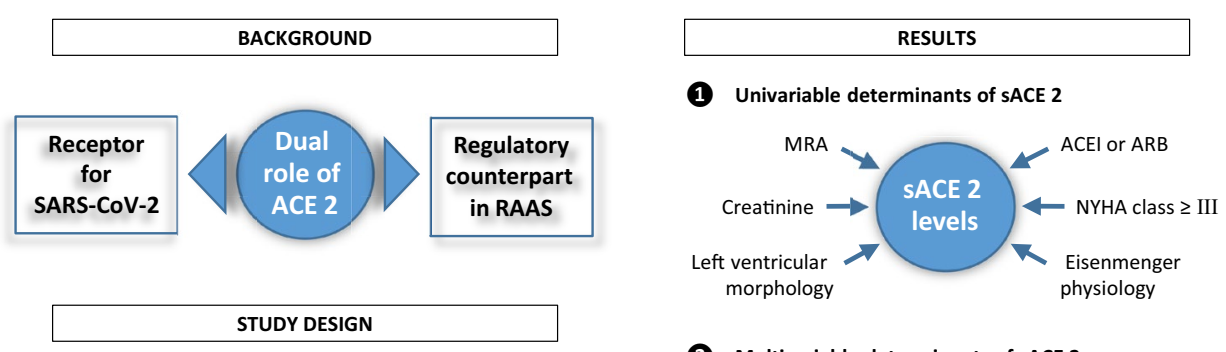

182 patients with complex congenital heart disease

$\rightarrow$ Clinical parameters (NYHA class, medication)

$\rightarrow$ Echocardiography (EF of systemic ventricle)

$\rightarrow$ Routine laboratory measurements

$\rightarrow$ Measurement of NT-proBNP, hsTNT and soluble ACE 2 (SACE 2) concentrations

\begin{tabular}{l|l|l|}
\hline \multicolumn{2}{|c|}{ Multivariable determinants of SACE 2} \\
\hline Variable & $\begin{array}{l}\text { Regression coefficient } \\
(95 \% \mathrm{CI})\end{array}$ & p-value \\
\hline NYHA class $\geq$ III & $0.324(0.117-0.530)$ & 0.002 \\
\hline Creatinine & $0.274(0.007-0.540)$ & 0.044 \\
\hline ACEI or ARB & $-0.221(-0.356--0.087)$ & 0.001 \\
\hline
\end{tabular}

Extended author information available on the last page of the article 
Keywords Soluble ACE2 $\cdot$ Complex congenital heart disease $\cdot$ Heart failure $\cdot$ COVID-19

\section{Introduction}

Angiotensin-converting enzyme 2 (ACE2) is a membranebound carboxymonopeptidase that converts Angiotensin I and Angiotensin II into Angiotensin 1-9 and Angiotensin $1-7$, respectively, and is highly expressed on the surface of different organ cells in the heart, lungs, kidneys and testis [1-3]. The soluble form of ACE2 (by proteolytic shedding of membrane-bound ACE2) is also a key component of the counter-regulatory pathway within the renin-angiotensin-aldosterone system (RAAS) which plays a crucial role in the regulation of blood pressure, heart failure, diabetes and chronic kidney disease [4-6].

The current coronavirus SARS-CoV-2 uses ACE2 as a cellular receptor to invade target cells. In particular, the spike protein of SARS-CoV-2 is processed by transmembrane protease-serine 2 and favors the binding of the spike protein to ACE2 to enter the host cells [6]. To date, an increasing number of publications have confirmed the role of ACE2 receptor for the cell entry mechanism of SARS-CoV-2 in the current pandemic $[2,3,6]$. Several epidemiological studies have also shown the severity of the SARS-CoV-2 disease (COVID-19) in older patients and particularly those with cardiovascular rather than pulmonary predisposing risk factors [7-9]. Thus, sACE2 concentrations were found to be elevated in men and older patients with different cardiovascular morbidities, such as hypertension, diabetes, coronary heart disease and heart failure [8,10-14]. These interactions of ACE2 may explain the higher vulnerability and predisposition of such patients to have a severe or fatal outcome after SARS-CoV-2 infection [15-17].

Adult patients with complex congenital heart disease (CHD) may also represent a vulnerable group of patients due to comorbidities, residual heart defects with longstanding pressure or volume overload as well as reduced intrinsic myocardial function finally resulting in symptomatic heart failure in early or mid-term adulthood [18]. Data on the SARS-CoV-2 infection rate in patients with CHD are still lacking. According to data from different countries and the Johns Hopkins University, children and young people seem to have a less severe time course and fatality rate with COVID-19 than older adults $[19,20]$ what may be due to lower sACE2 levels [21]. Moreover, an increased vulnerability of older and male patients with cardiovascular disease or heart failure can be seen that could also be related to increased sACE2 levels [10-12, 22]. In adult patients with complex CHD who often present with altered myocardial function or even symptomatic heart failure, data on SACE2 levels are lacking. Thus, in the light of the dual role of ACE2 during the current pandemic, the aim of our study was to assess SACE2 levels in this particular patient cohort and to evaluate determinants of SACE2 concentrations with special emphasis on factors that are independently associated with increased SACE2 concentrations.

\section{Methods}

\section{Patients}

In our outpatient clinic for adults with CHD, several prospective studies for the evaluation of different biomarkers in serum as well as micro-RNA signatures in whole blood had been performed in the past [23-25]. To assess sACE2 concentrations, existing serum samples of these patients frozen at $-80^{\circ} \mathrm{C}$ representing the pre-COVID-19 era were used for analysis. Thus, serum samples of 182 consecutive patients with complex $\mathrm{CHD} \geq 18$ years of age who were regularly seen in our outpatient clinic between 22/01/2015 and 02/12/2019 were analyzed in the present study. Complex CHD was classified according to current ACC/AHA guidelines [26] and mainly related to severe congenital heart defects including all forms of pulmonary atresia, cyanotic CHD, Eisenmenger syndrome, transposition of the great arteries (TGA), common arterial trunk, all kinds of single ventricle physiology with or without Fontan palliation as well as CHD at increased risk for heart failure, such as tetralogy of Fallot [27]. Patients with mild or moderate CHD, pregnancy, severe renal dysfunction or dialysis and incapability to understand or sign informed consent were excluded. Of the 182 patients enrolled in the study, 60/182 (33.0\%) patients had corrective surgery of congenital right heart disease (CRHD), such as pulmonary atresia, tetralogy of Fallot or common arterial trunk, 62/182 (34.1\%) patients had TGA of whom 40/62 (64.5\%) patients had a systemic morphological right ventricle (TGA-RV) and 22/62 (35.5\%) patients a systemic morphological left ventricle (TGA-LV) after arterial switch operation, 37/182 (20.3\%) patients showed a single ventricle physiology after complete Fontan palliation (FONT) and in 23/182 (12.6\%) patients a noncorrected cyanotic heart defect or Eisenmenger syndrome classified as Eisenmenger physiology (EIS) was present. Mean age was $30.1 \pm 10.5$ years (range $18-62$ years) and 103 patients were male (56.6\%). The study protocol has been described in detail previously [23]. 63 healthy subjects with a mean age of $31.6 \pm 11.7$ years (range 18-61 years) served as controls. The control group was mainly recruited within our institution and consisted of medical students, medical staff or family members. To rule out a hemodynamically relevant heart abnormality, a physical examination and 
two-dimensional echocardiography were performed in all healthy participants. Clinical data of controls and patients are given in Table 1. All patients and healthy controls gave written informed consent before enrollment.

\section{Data and biochemical analyses}

Clinical data of the patients were collected from medical records. Echocardiographic data sets were analysed on an Echopac server (Echopac Version 6, GE Healthcare, Horten, Norway) and assessed by investigators blinded to the laboratory results.

Venous blood samples were drawn into standard sampling tubes shortly after echocardiography, centrifuged at $3000 \mathrm{~g}$ and serum removed, allocated and frozen at $-80{ }^{\circ} \mathrm{C}$ before analysis of ACE2 levels. In the patient group, routine laboratory tests, such as liver function tests and creatinine measurements, were performed using standard laboratory techniques. NT-proBNP and high sensitive troponin T levels were measured using an electrochemiluminescence sandwich immunoassay $\left(\right.$ Cobas ${ }^{\circledR}$ proBNP II and troponin T hs STAT, Roche Diagnostics, Basel, Switzerland) on the Elecsys ${ }^{\circledR} 2010$ analyzer. Levels of ACE2 were measured using a commercially available sandwich enzyme immunoassay (Human ACE $2^{\circledR}$, Cloud-Clone Corporation, Houston, Texas, USA) on the FLUOstar ${ }^{\circledR}$ Omega Microplate Reader (BMG LABTECH Inc., Cary, North Carolina, USA) and has been described in detail previously [28]. All biochemical analyses were performed by investigators blinded to the clinical and echocardiographic data of the patients. Glomerular filtration rate (GFR) was estimated using the chronic kidney disease epidemiology collaboration (CKD-EPI) creatinine equation [29].

\section{Statistical analysis}

Data were analysed using standard statistical software (SPSS version 25; SPSS Inc., Chicago, Illinois). Continuous variables are expressed as mean \pm standard deviation or median (interquartile interval) as appropriate. Differences between unpaired groups were analysed using a Mann-Whitney $U$ or Kruskal-Wallis test for continuous variables and a chisquare test for nominal variables. Linear regression analysis was used in a univariable and multivariable way to identify determinants of sACE2 levels. For regression analysis, sACE2 concentrations were $\log _{10}$ transformed due to the skewed distribution. In the multivariable model, variables were entered that gave statistically significant values in the univariable model and did not show any multicollinearity. The multivariable model was based on forward stepwise regression. A two-tailed $p$ value $<0.05$ was considered statistically significant.

\section{Results}

\section{Study population and SACE2 levels}

Clinical characteristics of patients based on quartile serum sACE2 concentrations are shown in Table 2. In patients with complex CHD, sACE2 levels ranged from 55.0 to $4526.1 \mathrm{pg} /$ $\mathrm{ml}$ with a median of $761.9 \mathrm{pg} / \mathrm{ml}(419.2-1277.7 \mathrm{pg} / \mathrm{ml})$ and were significantly elevated as compared to healthy controls showing a median sACE2 level of $365.2 \mathrm{pg} / \mathrm{ml}$ (237.7-656.3 pg/ml; $p<0.001)$. Significantly elevated sACE2 levels were found in all subgroups of CHD patients in comparison to the healthy control group with highest
Table 1 Comparison of healthy controls and patients

\begin{tabular}{lllr}
\hline Variables & Healthy controls $(n=63)$ & All patients $(n=182)$ & $p$ value* \\
\hline Age at enrollment (years) & $31.6 \pm 11.7$ & $30.1 \pm 10.5$ & 0.474 \\
Male sex & $39 / 63(61.9 \%)$ & $103 / 182(56.6 \%)$ & 0.462 \\
Body mass index $\left(\mathrm{kg} / \mathrm{m}^{2}\right)$ & $23.2 \pm 3.3$ & $23.9 \pm 4.8$ & 0.579 \\
NYHA class & $1.0 \pm 0$ & $1.5 \pm 0.7$ & $<0.001$ \\
Systolic blood pressure $(\mathrm{mmHg})$ & $120.8 \pm 10.9$ & $123.3 \pm 13.9$ & 0.304 \\
Diastolic blood pressure $(\mathrm{mmHg})$ & $70.2 \pm 7.7$ & $70.8 \pm 9.4$ & 0.829 \\
Transcutaneous oxygen saturation at rest $(\%)$ & $98.2 \pm 1.2$ & $95.0 \pm 5.9$ & $<0.001$ \\
Ejection fraction of SV $(\%)$ & $62.4 \pm 4.4$ & $54.9 \pm 9.1$ & $<0.001$ \\
Enddiastolic volume of SV (ml) & $107.9 \pm 26.9$ & $131.9 \pm 62.2$ & 0.006 \\
Endsystolic volume of SV (ml) & $40.5 \pm 12.6$ & $61.9 \pm 37.7$ & $<0.001$ \\
VTI above aortic valve $(\mathrm{cm})$ & $27.4 \pm 4.3$ & $24.4 \pm 4.5$ & $<0.001$ \\
sACE2 concentrations $(\mathrm{pg} / \mathrm{ml})$ & $365.2(237.7-656.3)$ & $761.9(419.2-1277.7)$ & $<0.001$ \\
\hline
\end{tabular}

Mean \pm standard deviation or median (interquartile interval) are used

NYHA New York Heart Association, SV systemic ventricle, VTI velocity time integral, sACE2 soluble angiotensin-converting enzyme 2

*Mann-Whitney $U$ test 
Table 2 Baseline characteristics of patients according to sACE2 quartiles

\begin{tabular}{|c|c|c|c|c|c|}
\hline Variables & $\begin{array}{l}\text { Quartile 1 } \\
(<419.2) \\
(n=45)\end{array}$ & $\begin{array}{l}\text { Quartile } 2(419.2-761.9) \\
(n=46)\end{array}$ & $\begin{array}{l}\text { Quartile } 3(761.9-1277.7) \\
(n=46)\end{array}$ & $\begin{array}{l}\text { Quartile 4 } \\
(>1277.7) \\
(n=45)\end{array}$ & $p$ value* \\
\hline Age at enrollment (years) & $30.4 \pm 9.8$ & $29.5 \pm 10.1$ & $29.2 \pm 10.2$ & $31.4 \pm 12.0$ & 0.757 \\
\hline Male sex & $25 / 45(55.6 \%)$ & $25 / 46(54.3 \%)$ & $28 / 46(60.9 \%)$ & $25 / 45(55.6 \%)$ & 0.925 \\
\hline NYHA class & $1.4 \pm 0.5$ & $1.4 \pm 0.5$ & $1.5 \pm 0.7$ & $1.8 \pm 0.8$ & 0.090 \\
\hline Systolic blood pressure (mmHg) & $122.9 \pm 12.0$ & $125.1 \pm 14.8$ & $121.6 \pm 13.9$ & $123.6 \pm 15.0$ & 0.849 \\
\hline Diastolic blood pressure $(\mathrm{mmHg})$ & $69.6 \pm 7.6$ & $72.4 \pm 9.8$ & $69.7 \pm 9.3$ & $71.6 \pm 10.7$ & 0.489 \\
\hline $\begin{array}{l}\text { Transcutaneous oxygen saturation } \\
\text { at rest }(\%)\end{array}$ & $96.8 \pm 2.8$ & $96.3 \pm 6.2$ & $94.8 \pm 5.8$ & $92.2 \pm 8.2$ & 0.012 \\
\hline Presence of atrial fibrillation & $0 / 45(0 \%)$ & $1 / 46(2.2 \%)$ & $2 / 46(4.3 \%)$ & $3 / 45(6.7 \%)$ & 0.326 \\
\hline Left ventricular morphology of SV & $25 / 45(55.6 \%)$ & $31 / 46(67.4 \%)$ & $39 / 46(84.8 \%)$ & $33 / 45(73.3 \%)$ & 0.160 \\
\hline Ejection fraction of SV (\%) & $55.2 \pm 8.5$ & $56.5 \pm 8.1$ & $55.2 \pm 9.4$ & $53.0 \pm 10.3$ & 0.326 \\
\hline VTI above aortic valve (cm) & $24.4 \pm 3.9$ & $25.8 \pm 4.8$ & $24.0 \pm 4.7$ & $23.6 \pm 4.2$ & 0.200 \\
\hline Creatinine (mg/dl) & $0.81(0.75-0.95)$ & $0.85(0.71-0.96)$ & $0.85(0.75-0.95)$ & $0.94(0.81-1.09)$ & 0.013 \\
\hline Estimated GFR (ml/min) & $106.9(96.5-117.6)$ & $109.5(96.3-121.8)$ & $109.5(91.3-120.2)$ & $99.6(71.7-118.5)$ & 0.313 \\
\hline NT-proBNP (ng/l) & $151.0(64.5-236.3)$ & $206.4(87.8-314.9)$ & $125.5(67.0-237.2)$ & $255.3(89.6-627.7)$ & 0.022 \\
\hline High sensitive troponin $\mathrm{T}(\mathrm{pg} / \mathrm{ml})$ & $5.0(3.0-6.0)$ & $4.0(3.0-8.0)$ & $5.0(3.0-7.0)$ & $5.0(3.0-13.5)$ & 0.496 \\
\hline \multicolumn{6}{|l|}{ Medication } \\
\hline ACEI or ARB & $14 / 45(31.1 \%)$ & $8 / 46(17.4 \%)$ & $9 / 46(19.6 \%)$ & $5 / 45(11.1 \%)$ & 0.116 \\
\hline$\beta$-blockers & $13 / 45(28.9 \%)$ & $10 / 46(21.7 \%)$ & $15 / 46(32.6 \%)$ & $17 / 45(37.8 \%)$ & 0.402 \\
\hline MRA & $3 / 45(6.7 \%)$ & $7 / 46(15.2 \%)$ & $9 / 46(19.6 \%)$ & $11 / 45(24.4 \%)$ & 0.135 \\
\hline Loop diuretics or thiazides & $10 / 45(22.2 \%)$ & $9 / 46(19.6 \%)$ & $11 / 46(23.9 \%)$ & $18 / 45(40.0 \%)$ & 0.116 \\
\hline Antiarrhythmics & $2 / 45(4.4 \%)$ & $0 / 46(0 \%)$ & $3 / 46(6.5 \%)$ & $7 / 45(15.6 \%)$ & 0.072 \\
\hline
\end{tabular}

Mean \pm standard deviation or median (interquartile interval) are used

sACE2 soluble angiotensin-converting enzyme 2, NYHA New York Heart Association, SV systemic ventricle, VTI velocity time integral, GFR glomerular filtration rate, $A C E I$ angiotensin-converting enzyme inhibitors, $A R B$ angiotensin receptor blockers, $M R A$ mineralocorticoid receptor antagonists

*Kruskal-Wallis test

levels seen in patients with Eisenmenger physiology (median 1418.4 pg/ml) (Fig. 1). Moreover, patients with a systemic morphological left ventricle displayed higher sACE2 levels than those with a systemic morphological right ventricle (median $841.7 \mathrm{pg} / \mathrm{ml}$ vs $633.9 \mathrm{pg} / \mathrm{ml}, p=0.026$ ). Soluble ACE2 levels were also significantly increased in patients with a higher NYHA class $\geq$ III reflecting advanced heart failure as compared to patients with NYHA class I/II (median $1856.2 \mathrm{pg} / \mathrm{ml}$ vs $714.5 \mathrm{pg} / \mathrm{ml}, p<0.001$ ) (Fig. 2).

\section{Association of SACE2 levels with different variables}

Linear regression analysis revealed that higher sACE2 levels were significantly correlated with a higher NYHA class $\geq$ III, the presence of Eisenmenger physiology representing more severe CHD, a left ventricular morphology of the systemic ventricle, higher creatinine levels as well as the use of mineralocorticoid receptor antagonists (MRA) in the univariable model (Table 3). In contrast, the use of ACE inhibitors (ACEI) or angiotensin receptor blockers (ARB) was associated with lower sACE2 levels. Interestingly,
SACE2 concentrations were only weakly related to NTproBNP $(r=0.127, p=0.024)$ or high sensitive troponin $\mathrm{T}$ levels $(r=0.274, p=0.010)$ in our study cohort.

In the multivariable model, however, the most significant factor independently associated with higher levels of sACE2 was found to be a higher NYHA class $\geq$ III $(p=0.002)$ whereas the use of ACEI or ARB was the most significant factor associated with lower levels of sACE2 $(p=0.001)$.

\section{Discussion}

In our study, significantly higher sACE2 serum levels were found in adult patients with complex CHD in comparison to healthy controls indicating the relationship of ACE2 expression to cardiovascular disease. Soluble ACE2 levels differed significantly between the studied CHD subgroups with highest concentrations found in the EIS subgroup, thus reflecting the severity of CHD (Fig. 1). Interestingly, patients with TGA-LV after the arterial switch procedure showed higher sACE2 levels than those with TGA-RV after the atrial switch 
Fig. 1 Boxplots displaying sACE2 levels in healthy controls and patients with various types of congenital heart defects. $* p<0.05, * * p=0.001$, $* * * p<0.001$ as compared to controls. $C R H D$ corrected congenital right heart disease, $T G A$ transposition of the great arteries, $R V$ systemic right ventricle, FONT Fontan palliation, $L V$ systemic left ventricle, $E I S$ Eisenmenger physiology
Fig. 2 Boxplots illustrating sACE2 levels in patients with NYHA class I/II compared to NYHA class $\geq$ III
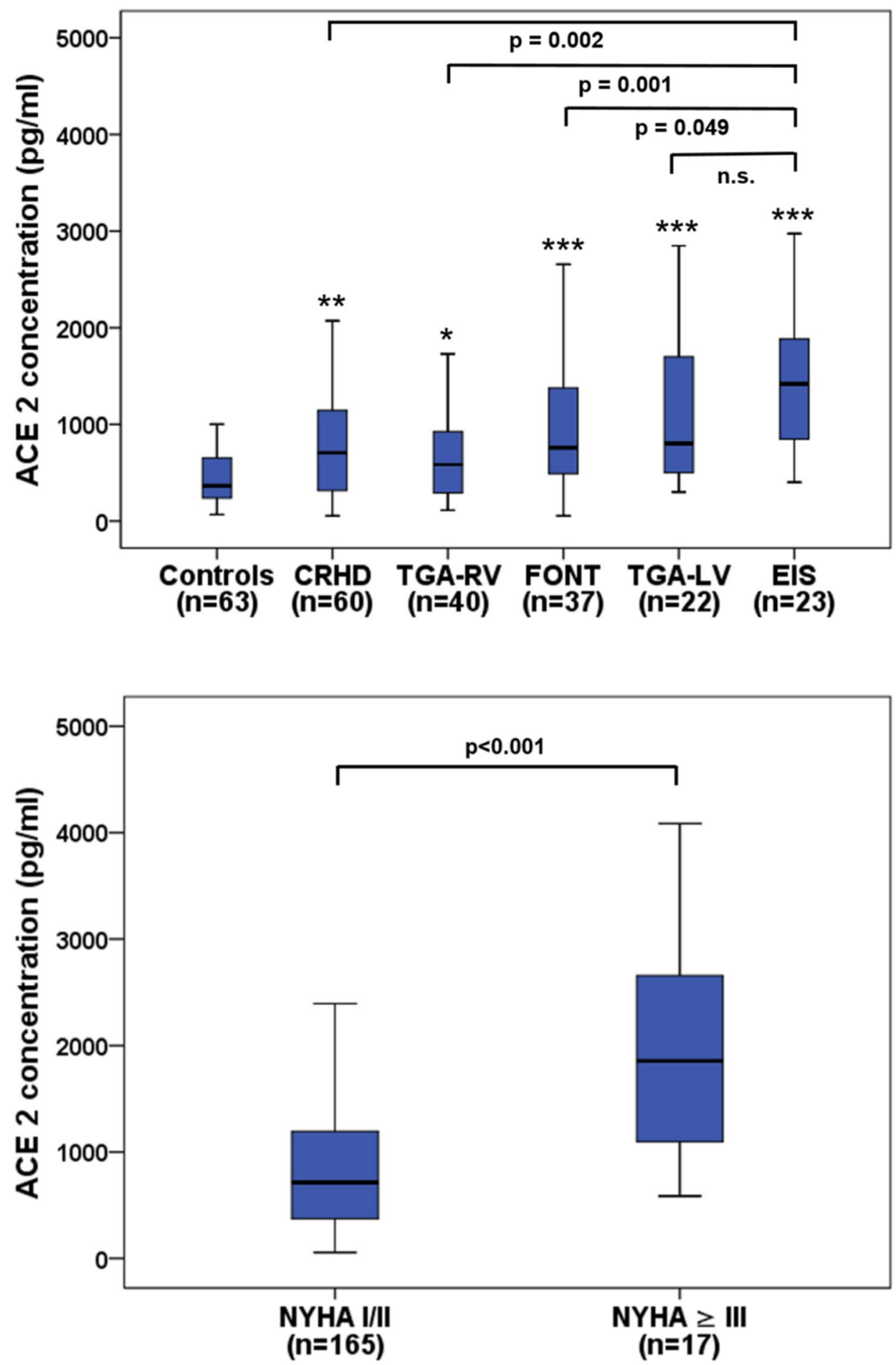

operation what may be due to the morphology of the systemic ventricle since patients with a systemic morphological right ventricle showed lower sACE2 levels than those with a systemic morphological left ventricle. In addition, sACE2 concentrations were significantly increased in patients with NYHA class $\geq$ III reflecting advanced heart failure (Fig. 2).

\section{Soluble ACE2 levels in other patient cohorts}

Our results are consistent with a previous study illustrating increasing plasma sACE2 concentrations according to NYHA class in heart failure patients with highest levels found in the acute setting [30]. Moreover, in that study, sACE2 concentrations were found to be elevated in patients 
Table 3 Univariable and multivariable linear regression analysis for determinants of sACE2 levels

\begin{tabular}{|c|c|c|c|c|}
\hline & \multicolumn{2}{|c|}{ Univariable analysis } & \multicolumn{2}{|l|}{ Multivariable analysis } \\
\hline & $\begin{array}{l}\text { Regression } \\
\text { coefficient }\end{array}$ & $p$ value & Regression coefficient $(95 \%$ CI) & $p$ value \\
\hline Age at enrollment & -0.001 & 0.835 & - & - \\
\hline Male sex & 0.018 & 0.756 & - & - \\
\hline NYHA class $\geq$ III & 0.414 & $<0.001$ & $0.324(0.117-0.530)$ & 0.002 \\
\hline Diagnosis of EIS & 0.313 & $<0.001$ & - & - \\
\hline Presence of atrial fibrillation & 0.301 & 0.065 & - & - \\
\hline Left ventricular morphology of SV & 0.138 & 0.028 & - & - \\
\hline Transcutaneous oxygen saturation at rest & -0.019 & $<0.001$ & - & - \\
\hline Creatinine & 0.436 & 0.001 & $0.274(0.007-0.540)$ & 0.044 \\
\hline Glomerular filtration rate & -0.003 & 0.027 & - & - \\
\hline \multicolumn{5}{|l|}{ Medication } \\
\hline ACEI or ARB & -0.202 & 0.006 & $-0.221(-0.356-0.087)$ & 0.001 \\
\hline$\beta$-blockers & 0.023 & 0.713 & - & - \\
\hline MRA & 0.167 & 0.034 & - & - \\
\hline Loop diuretics or thiazides & 0.121 & 0.067 & - & - \\
\hline Antiarrhythmics & 0.219 & 0.053 & - & - \\
\hline
\end{tabular}

SACE2 soluble angiotensin-converting enzyme 2, NYHA New York Heart Association, EIS Eisenmenger physiology, ACEI ACE inhibitors, $A R B$ angiotensin receptor blockers, MRA mineralocorticoid receptor antagonists receiving MRA or loop diuretics whereas no difference was seen with the use of ACEI or ARB medication. Although brain natriuretic peptide levels were significantly related to sACE2 levels in that study, correlation of NT-proBNP with sACE2 was rather weak in our cohort of patients.

Elevated sACE2 levels were also detected in male and female patients with coronary heart disease using the same sACE2 assay by Cloud-Clone Corporation as in our study [31]. Surprisingly, the coronary heart disease patients displayed markedly higher sACE2 concentrations (about 5000-6000 pg/ml) than our CHD patients with NYHA class $\geq$ III (approximately $2000 \mathrm{pg} / \mathrm{ml}$ ). These differences may be due to the different cardiovascular comorbidities (e.g. higher prevalence of cardiovascular risk factors, such as arterial hypertension or diabetes) and the ischemic pathophysiology of altered myocardial function in the cohort with coronary heart disease. Hence, sACE2 levels were also significantly higher in patients with multi-vessel than singlevessel disease in that study. In contrast, altered myocardial function in CHD patients is mainly due to longstanding pressure or volume overload.

\section{Determinants of sACE2 levels}

In the linear regression analysis, increased sACE2 levels were significantly related to a higher NYHA class $\geq$ III, more severe CHD, left ventricular morphology of the systemic ventricle, higher creatinine values and the use of MRA in the univariable model (Table 2). However, multivariable analysis revealed that a higher NYHA class $\geq$ III was the most significant determinant that was independently associated with higher SACE2 concentrations. In addition, the use of ACEI or ARB medication was independently associated with lower SACE2 concentrations. Our results are in accordance with a previous study investigating two independent cohorts of patients with left heart failure illustrating that ACEI or ARB uses were independent predictors of lower sACE2 concentrations whereas the use of MRA was an independent predictor of higher SACE2 concentrations [22]. In contrast to that study, however, sACE2 levels were not found to be higher in male or older patients in our study population what may be due to the different age of the studied patients. In our CHD cohort, patients were rather young with a mean age of about 30 years in contrast to the older age of the patients studied by Sama et al. with a median age of 70 years [22].

\section{Study limitations}

Our study had some limitations that need to be addressed. First, evaluation of the direct association of the measured sACE2 concentrations and the infection risk or severity of COVID-19 disease is currently not possible because data on the incidence of COVID-19 disease is not yet available for our study cohort. Moreover, sACE2 concentrations may not necessarily represent membrane-bound ACE2 expression because previous studies indicate that ACE2 shedding is mediated by a disintegrin and metalloproteinase 
(ADAM)-17 and may not be applied to the total extent of tissue-bound ACE2 activity [32-34]. Thus, the relation of sACE2 and the extent of ADAM-17 activity or membranebound ACE2 shedding is still unclear. Nevertheless, in the clinical setting, male sex, older age, the presence of cardiovascular risk factors or heart failure are known to be highly predictive for a severe course of COVID-19 disease $[8,16]$ and could be due to increased sACE2 concentrations [21, $22,35]$. However, further studies are warranted to evaluate the direct relationship of SACE2 concentrations and the susceptibility or course of COVID-19 disease in adult patients with complex CHD.

\section{Conclusion}

Soluble ACE2 concentrations were significantly elevated in adults with various types of complex CHD as compared to healthy controls with highest levels found in those with Eisenmenger physiology or a higher NYHA-class $\geq$ III reflecting advanced heart failure. However, a higher NYHA class $\geq$ III was the most significant determinant that was independently associated with increased sACE2 levels.

Acknowledgements This work was supported by the German Heart Foundation, Frankfurt/Main, Germany, for the research on adults with congenital heart disease

Funding Open Access funding enabled and organized by Projekt DEAL.

\section{Compliance with ethical standards}

Conflict of interest The authors declare that they have no conflict of interest.

Ethical standard The study has been performed in accordance with the ethical standards of the 1964 Declaration of Helsinki and its later amendments, was approved by the local ethics committee (i.e. the Saarland Medical Association ethical board, approval no. 73/09) and all participants gave written and informed consent before enrollment.

Open Access This article is licensed under a Creative Commons Attribution 4.0 International License, which permits use, sharing, adaptation, distribution and reproduction in any medium or format, as long as you give appropriate credit to the original author(s) and the source, provide a link to the Creative Commons licence, and indicate if changes were made. The images or other third party material in this article are included in the article's Creative Commons licence, unless indicated otherwise in a credit line to the material. If material is not included in the article's Creative Commons licence and your intended use is not permitted by statutory regulation or exceeds the permitted use, you will need to obtain permission directly from the copyright holder. To view a copy of this licence, visit http://creativecommons.org/licenses/by/4.0/.

\section{References}

1. Donoghue M, Hsieh F, Baronas E, Godbout K, Gosselin M, Stagliano N, Donovan M, Woolf B, Robison K, Jeyaseelan R, Breitbart RE, Acton S (2000) A novel angiotensin-converting enzyme-related carboxypeptidase (ACE2) converts angiotensin I to angiotensin 1-9. Circ Res 87:E1-9. https://doi.org/10.1161/01. res.87.5.e1

2. Li W, Moore MJ, Vasilieva N, Sui J, Wong SK, Berne MA, Somasundaran M, Sullivan JL, Luzuriaga K, Greenough TC, Choe H, Farzan M (2003) Angiotensin-converting enzyme 2 is a functional receptor for the SARS coronavirus. Nature 426:450-454. https://doi.org/10.1038/nature02145

3. Letko M, Marzi A (2020) Functional assessment of cell entry and receptor usage for SARS-CoV-2 and other lineage B betacoronaviruses. Nat Microbiol 5:562-569. https://doi.org/10.1038/s4156 4-020-0688-y

4. Patel VB, Zhong JC, Grant MB, Oudit GY (2016) Role of the ACE2/angiotensin 1-7 axis of the renin-angiotensin system in heart failure. Circ Res 118:1313-1326. https://doi.org/10.1161/ circresaha.116.307708

5. Wang K, Gheblawi M, Oudit GY (2020) Angiotensin converting enzyme 2: a double-edged sword. Circulation 142:426-428. https ://doi.org/10.1161/circulationaha.120.047049

6. Gheblawi M, Wang K, Viveiros A, Nguyen Q, Zhong JC, Turner AJ, Raizada MK, Grant MB, Oudit GY (2020) Angiotensinconverting enzyme 2: SARS-CoV-2 receptor and regulator of the renin-angiotensin system: celebrating the 20th anniversary of the discovery of ACE2. Circ Res 126:1456-1474. https://doi. org/10.1161/circresaha.120.317015

7. Huang C, Wang Y, Li X, Ren L, Zhao J, Hu Y, Zhang L, Fan G, Xu J, Gu X, Cheng Z, Yu T, Xia J, Wei Y, Wu W, Xie X, Yin W, Li H, Liu M, Xiao Y, Gao H, Guo L, Xie J, Wang G, Jiang R, Gao Z, Jin Q, Wang J, Cao B (2020) Clinical features of patients infected with 2019 novel coronavirus in Wuhan, China. Lancet 395:497-506. https://doi.org/10.1016/s0140-6736(20)30183-5

8. Zhou F, Yu T, Du R, Fan G, Liu Y, Liu Z, Xiang J, Wang Y, Song B, Gu X, Guan L, Wei Y, Li H, Wu X, Xu J, Tu S, Zhang Y, Chen H, Cao B (2020) Clinical course and risk factors for mortality of adult inpatients with COVID-19 in Wuhan, China: a retrospective cohort study. Lancet 395:1054-1062. https://doi.org/10.1016/ s0140-6736(20)30566-3

9. Li X, Molina-Molina M, Abdul-Hafez A, Uhal V, Xaubet A, Uhal BD (2008) Angiotensin converting enzyme-2 is protective but downregulated in human and experimental lung fibrosis. Am J Physiol Lung Cell Mol Physiol 295:L178-185. https://doi. org/10.1152/ajplung.00009.2008

10. Diaz JH (2020) Hypothesis: angiotensin-converting enzyme inhibitors and angiotensin receptor blockers may increase the risk of severe COVID-19. J Travel Med. https://doi.org/10.1093/jtm/ taaa041

11. Kuster GM, Pfister O, Burkard T, Zhou Q, Twerenbold R, Haaf P, Widmer AF, Osswald S (2020) SARS-CoV2: should inhibitors of the renin-angiotensin system be withdrawn in patients with COVID-19? Eur Heart J 41:1801-1803. https://doi.org/10.1093/ eurheartj/ehaa235

12. Goulter AB, Goddard MJ, Allen JC, Clark KL (2004) ACE2 gene expression is up-regulated in the human failing heart. BMC Med 2:19. https://doi.org/10.1186/1741-7015-2-19

13. Culebras E, Hernández F (2020) ACE2 is on the X chromosome: could this explain COVID-19 gender differences? Eur Heart J 41:3095. https://doi.org/10.1093/eurheartj/ehaa521 
14. Li S, Wang Z, Yang X, Hu B, Huang Y, Fan S (2017) Association between circulating angiotensin-converting enzyme 2 and cardiac remodeling in hypertensive patients. Peptides 90:63-68. https:// doi.org/10.1016/j.peptides.2017.02.007

15. Karlberg J, Chong DS, Lai WY (2004) Do men have a higher case fatality rate of severe acute respiratory syndrome than women do? Am J Epidemiol 159:229-231. https://doi.org/10.1093/aje/kwh05 6

16. Onder G, Rezza G, Brusaferro S (2020) Case-fatality rate and characteristics of patients dying in relation to COVID-19 in Italy. JAMA 323:1775-1776. https://doi.org/10.1001/jama.2020.4683

17. Palmieri L, Vanacore N, Donfrancesco C, Lo Noce C, Canevelli M, Punzo O, Raparelli V, Pezzotti P, Riccardo F, Bella A, Fabiani M, D’Ancona FP, Vaianella L, Tiple D, Colaizzo E, Palmer K, Rezza G, Piccioli A, Brusaferro S, Onder G (2020) Clinical characteristics of hospitalized individuals dying with COVID-19 by age group in Italy. J Gerontol A Biol Sci Med Sci 75:1796-1800. https://doi.org/10.1093/gerona/glaa146

18. Stout KK, Broberg CS, Book WM, Cecchin F, Chen JM, Dimopoulos K, Everitt MD, Gatzoulis M, Harris L, Hsu DT, Kuvin JT, Law Y, Martin CM, Murphy AM, Ross HJ, Singh G, Spray TL (2016) Chronic Heart Failure in Congenital Heart Disease: a Scientific Statement From the American Heart Association. Circulation 133:770-801. https://doi.org/10.1161/cir.000000000000035 2

19. Liguoro I, Pilotto C, Bonanni M, Ferrari ME, Pusiol A, Nocerino A, Vidal E, Cogo P (2020) SARS-COV-2 infection in children and newborns: a systematic review. Eur J Pediatr 179:1029-1046. https://doi.org/10.1007/s00431-020-03684-7

20. Grasselli G, Zangrillo A, Zanella A, Antonelli M, Cabrini L, Castelli A, Cereda D, Coluccello A, Foti G, Fumagalli R, Iotti G, Latronico N, Lorini L, Merler S, Natalini G, Piatti A, Ranieri MV, Scandroglio AM, Storti E, Cecconi M, Pesenti A (2020) Baseline characteristics and outcomes of 1591 patients infected with SARS-CoV-2 admitted to ICUs of the Lombardy Region, Italy. JAMA 323:1574-1581. https://doi.org/10.1001/jama.2020.5394

21. Swärd P, Edsfeldt A, Reepalu A, Jehpsson L, Rosengren BE, Karlsson MK (2020) Age and sex differences in soluble ACE2 may give insights for COVID-19. Crit Care 24:221. https://doi. org/10.1186/s13054-020-02942-2

22. Sama IE, Ravera A, Santema BT, van Goor H, Ter Maaten JM, Cleland JGF, Rienstra M, Friedrich AW, Samani NJ, Ng LL, Dickstein K, Lang CC, Filippatos G, Anker SD, Ponikowski P, Metra M, van Veldhuisen DJ, Voors AA (2020) Circulating plasma concentrations of angiotensin-converting enzyme 2 in men and women with heart failure and effects of renin-angiotensinaldosterone inhibitors. Eur Heart J 41:1810-1817. https://doi. org/10.1093/eurheartj/ehaa373

23. Laqqan M, Schwaighofer C, Graeber S, Raedle-Hurst T (2018) Predictive value of soluble ST2 in adolescent and adult patients with complex congenital heart disease. PLoS ONE 13:e0202406. https://doi.org/10.1371/journal.pone.0202406

24. Abu-Halima M, Meese E, Saleh MA, Keller A, Abdul-Khaliq H, Raedle-Hurst T (2019) Micro-RNA 150-5p predicts overt heart failure in patients with univentricular hearts. PLoS ONE 14:e0223606. https://doi.org/10.1371/journal.pone.0223606

25. Abu-Halima M, Meese E, Keller A, Abdul-Khaliq H, RadleHurst T (2017) Analysis of circulating microRNAs in patients with repaired Tetralogy of Fallot with and without heart failure. J Transl Med 15:156. https://doi.org/10.1186/s12967-017-1255-Z
26. Warnes CA, Williams RG, Bashore TM, Child JS, Connolly HM, Dearani JA, del Nido P, Fasules JW, Graham TP Jr, Hijazi ZM, Hunt SA, King ME, Landzberg MJ, Miner PD, Radford MJ, Walsh EP, Webb GD, Smith SC Jr, Jacobs AK, Adams CD, Anderson JL, Antman EM, Buller CE, Creager MA, Ettinger SM, Halperin JL, Hunt SA, Krumholz HM, Kushner FG, Lytle BW, Nishimura RA, Page RL, Riegel B, Tarkington LG, Yancy CW (2008) ACC/AHA 2008 guidelines for the management of adults with congenital heart disease: a report of the American College of Cardiology/ American Heart Association Task Force on Practice Guidelines (Writing Committee to Develop Guidelines on the Management of Adults With Congenital Heart Disease). Developed in Collaboration With the American Society of Echocardiography, Heart Rhythm Society, International Society for Adult Congenital Heart Disease, Society for Cardiovascular Angiography and Interventions, and Society of Thoracic Surgeons. J Am Coll Cardiol 52:e143-263. https://doi.org/10.1016/j.jacc.2008.10.001

27. Shaddy RE, Webb G (2008) Applying heart failure guidelines to adult congenital heart disease patients. Expert Rev Cardiovasc Ther 6:165-174. https://doi.org/10.1586/14779072.6.2.165

28. Chen YY, Zhang P, Zhou XM, Liu D, Zhong JC, Zhang CJ, Jin LJ, Yu HM (2018) Relationship between genetic variants of ACE2 gene and circulating levels of ACE2 and its metabolites. J Clin Pharm Ther 43:189-195. https://doi.org/10.1111/jcpt.12625

29. Levey AS, Stevens LA (2010) Estimating GFR using the CKD Epidemiology Collaboration (CKD-EPI) creatinine equation: more accurate GFR estimates, lower CKD prevalence estimates, and better risk predictions. Am J Kidney Dis 55:622-627. https ://doi.org/10.1053/j.ajkd.2010.02.337

30. Epelman S, Tang WH, Chen SY, Van Lente F, Francis GS, Sen S (2008) Detection of soluble angiotensin-converting enzyme 2 in heart failure: insights into the endogenous counter-regulatory pathway of the renin-angiotensin-aldosterone system. J Am Coll Cardiol 52:750-754. https://doi.org/10.1016/j.jacc.2008.02.088

31. Zhou X, Zhang P, Liang T, Chen Y, Liu D, Yu H (2020) Relationship between circulating levels of angiotensin-converting enzyme 2-angiotensin-(1-7)-MAS axis and coronary heart disease. Heart Vessels 35:153-161. https://doi.org/10.1007/s00380-019-01478-y

32. Larouche-Lebel É, Loughran KA, Oyama MA (2019) Plasma and tissue angiotensin-converting enzyme 2 activity and plasma equilibrium concentrations of angiotensin peptides in dogs with heart disease. J Vet Intern Med 33:1571-1584. https://doi.org/10.1111/ jvim. 15548

33. Lambert DW, Yarski M, Warner FJ, Thornhill P, Parkin ET, Smith AI, Hooper NM, Turner AJ (2005) Tumor necrosis factor-alpha convertase (ADAM17) mediates regulated ectodomain shedding of the severe-acute respiratory syndrome-coronavirus (SARS$\mathrm{CoV}$ ) receptor, angiotensin-converting enzyme-2 (ACE2). J Biol Chem 280:30113-30119. https://doi.org/10.1074/jbc.M5051 11200

34. Patel VB, Clarke N, Wang Z, Fan D, Parajuli N, Basu R, Putko B, Kassiri Z, Turner AJ, Oudit GY (2014) Angiotensin II induced proteolytic cleavage of myocardial ACE2 is mediated by TACE/ ADAM-17: a positive feedback mechanism in the RAS. J Mol Cell Cardiol 66:167-176. https://doi.org/10.1016/j.yjmcc.2013.11.017

35. Oudit GY, Pfeffer MA (2020) Plasma angiotensin-converting enzyme 2: novel biomarker in heart failure with implications for COVID-19. Eur Heart J 41:1818-1820. https://doi.org/10.1093/ eurheartj/ehaa414 


\section{Affiliations}

Tanja Raedle-Hurst ${ }^{1}\left(\mathbb{D} \cdot\right.$ Sarah Wissing ${ }^{1} \cdot$ Nils Mackenstein $^{1} \cdot$ Rima Obeid $^{2} \cdot$ Juergen Geisel $^{2} \cdot$ Stefan Wagenpfeil $^{3}$. Hashim Abdul-Khaliq ${ }^{1}$

$\triangle$ Tanja Raedle-Hurst tanja.raedle-hurst@uks.eu

1 Department of Pediatric Cardiology, Saarland University Medical Center, Homburg/Saar, Germany

2 Department of Clinical Chemistry and Laboratory Medicine, Saarland University Medical Center, Homburg/Saar, Germany

\author{
Institute of Medical Biometry, Epidemiology and Medical \\ Informatics, Saarland University Medical Center, \\ Homburg/Saar, Germany
}

